\title{
Finnish wild truffles: A review
}

\author{
Seema R. Bajaj, Salem Shamekh
}

\begin{abstract}
Wild edible fungi are a part of diet in various regions of the world, and are also known for their medicinal value. The scientific studies of wild truffle species in Scandinavian countries such as Finland have only started recently. The wild truffle species found and reported in Finland fall in the white truffle category. The growth and occurrence of truffles is affected by various soil parameters, host plants, and the environmental conditions. In this review article we discuss for the first time the less-reported white truffle species that have been found in Finland. The objective of this article is to provide an account of the parameters affecting the growth of Finnish white truffles such as chemical and physical properties of soil, environmental conditions, and the favourable host plant cultivar and discuss molecular tools used for their identification. The studies on these truffles have been compared with the ones from other regions of the world. Finally, we discuss the importance of the studies on the wild varieties of Finnish white truffles, need of further scientific studies, the possibility of using the knowledge for growing the truffle species with high economic value in international market, and subsequently it's potential to contribute to the economic growth of rural areas.
\end{abstract}

Index Terms - Finnish wild truffles; white truffles; Tuber anniae; T. foetidum.

\section{INTRODUCTION}

Truffles are the hypogeous fruiting bodies of the mycorrhizal fungi that belong to the genus Tuberaceae. Truffles were first recognised in the $18^{\text {th }}$ century, and till date, newer species are being identified across the globe [1]. Truffles have been bestowed upon with titles such as 'underground gold' and 'black diamond' due to their peculiar taste and aroma profile, and fluctuations in produce due to the period of cultivation and sensitivity to climatic conditions. Truffles are very much a part of Mediterranean, European, American, and Arabian cuisines. Along with their culinary appeal, truffle fruiting bodies have also been researched from nutraceutical perspective for their antiviral and antimicrobial activities, hepatoprotective activity, antioxidant capacities, anticancer and anti-inflammatory potential, and antimutagenic effects [2]. This is attributed to the presence of various polyphenolic compounds in truffles. Burgundy truffle [3] and various desert truffles [4] have been researched for this purpose extensively. However, many of the white truffle varieties are yet to be explored for their biological activities.

Truffles have been found to grow naturally in various climatic conditions ranging from the harsh desert climates [4]-[5] to the cold European climate [6] and now in the colder Scandinavian climate [7] with systematic scientific

Seema R. Bajaj, Muez Hest India Pvt. Ltd. 230\&231, Blue Rose Industrial Estate, WE Highway, Borivali (E), Mumbai 400066, India.

Salem Shamekh, Juva Truffle Center, Juva, Huttulantie 1C 51901, Finland. cultivation techniques. Many truffle species have been discovered in Finland by various researchers and confirmed genetically using sophisticated molecular techniques. Truffles that have been identified in various regions in Finland include T. anniae [8], T. foetidum [9], T. maculatum and $T$. scruposum [10]. Researchers have also reported the findings of $T$. anniae and attributed the occurrence of this truffle to the dispersal of Tuber between Europe and North America, possibly following the retreat of glaciers and reforestation of boreal regions during the Pleistocene [8]. Initially, the only truffle species of economic value which was naturally found in Finland was probably $T$. borchii (considering its identification is still under investigation). Such findings help promote systematic cultivation of truffle in newer regions, adding to the richness of culture and economics.

Cultivation of Mediterranean truffle varieties in the Scandinavian countries has been tried by many researchers. T. aestvium (the burgundy truffle), a highly priced truffle, was initially restricted to Southern France and Italy. It is now cultivated in Southern Sweden [7], Finland [1], and Poland [11]. Shamekh et al. (2014) systematically studied and reported successful cultivation of T. aestivum inoculated oak seedlings in the boreal Finnish climate. Highly esteemed European truffle species (Tuber aestivum Vittad. and $T$. borchii) were grown in a pecan orchard at North America which proposed an additional stream of revenue to the pecan growers in the region [12]. T. melanosporum naturally occurs in France, Spain, and Italy but in recent times its cultivation has been practiced in the truffle orchards of Australia [13]. This illustrates the possibility of cultivation of European truffle varieties outside its native region [1].

The globalization of cuisines has increased the demand for truffle flavours both in natural and artificial forms all over the world. This calls for an increased cultivation of truffles in both natural and induced forms. Since the popular truffles are a seasonal produce, their cultivation in Finland, where their season of harvest is different from rest of the Europe, has an advantage to provide a continuous supply and can help to increase profitability in the truffle business. T. melanosporum has a wholesale price of US\$ 800 per $\mathrm{kg}$ in European market which increases up to US\$ 1450 per $\mathrm{kg}$ when it is produced out-of-season in New Zealand and supplied to Europe [14]. Development and transfer of truffle cultivation techniques can help provide an uninterrupted supply of the popular truffles in fresh forms during all seasons, introduce concealed truffle varieties to the world, and generate new business opportunities.

Over 100 species of fungi have been taxonomically, morphologically or genetically classified as true truffles. These fungi are tropically dependent on certain host plant roots for the mycorrhizal symbiosis formation, and exchanging nutrients and carbon with their hosts. This means their incidence is further restricted by the range of their (potential) hosts [15]. The trees of choice for symbiosis are 
pine (Pinus spp.), fir (Abies spp.), birch (Betulaspp.), aspen (Populus spp.), oak (Quercus spp.), hazel (Corylusavellana L.), and rockrose (Cistus spp.) and also form mycorrhizas with orchids [8].

The truffles identified in the Finnish forests are in symbiosis with trees different from those reported for rest of Europe. For instance, in Finland, T. foetidum is associated with trees in the forests dominated by Norway spruce (Picea abies), with scattered birch (Betula spp.) and pine (Pinus sylvestris) in Lahti (100 km North of Helsinki) area of Finland [9]. Whereas, it grows in association with fagaceous trees (Quercus and Fagus) in southern Europe, in British Isles with Larix, in Denmark with deciduous forests and under hazel in Sweden. Spruce is not a commonly reported host tree for Tuber spp. [9].

Tuber maculatum has been collected in Southern Italy [16]. It is commonly found in Southern Europe, North America and has also been introduced in Australia, New Zealand by induced cultivation [17]. T. maculatum and T. borchii are both white truffles that are difficult to differentiate on the basis of morphological characteristics. The unambiguous differentiation using molecular probes is necessary for both economic and regulatory reasons since $T$. borchii is of value in the Italian food market (Mello et al., 2000). T. scruposum were also identified in the same environment in Lahti as $T$. maculatum [10].

The truffle species initially restricted to grow in certain regions of the globe, happen to disperse and recently grow in different regions due to various reasons. This review focuses on the existing few species of white truffle in Finnish forests and the parameters that influence their growth such as type and composition of soil, and host trees. This will help promote further systematic research towards identification and induced cultivation of truffle species of cultural as well as economic importance. Knowledge of various truffle cultivation and sophisticated analysis techniques is required in this process. This review paper also focuses on the various techniques of morphological and genetic evaluation for identification of white truffles. Finally, we shed light on the significance of the studies on truffle research, induced cultivation, and its possible economic role in rural areas of Finland.

\section{FINNISH WILD TRUFFLES AND THE NEED FOR THEIR STUDY}

Worldwide popularity of fresh truffles suggests the need to explore local varieties of truffles. The naturally existing (wild) white truffles have been discovered in several areas of Finland such as Puumala, Joensuu, Kotka, Turku, Lahti, Lohja, Espoo, and Lieksa among others (Fig. 1). The scientific literature available on Finnish white truffles is scant. Tuber anniae [8], T. foetidum [9], T. maculatum and T. scruposum [10] are few species among Finnish wild truffles which were studied and scientifically identified. Finnish truffle collectors are selling their findings to restaurants and consumers without proper knowledge of the truffle species. Thus, it is important to develop techniques in order to differentiate between the species of white truffle groups. There is a need for a profound study of the molecular characteristics of the different Finnish truffle deposits which will help identify the correct market value of truffle species of high economic worth such as T. borchii. The confirmed species descriptions can be presented in the Catalogue of the commercial mushrooms (Kauppasieniluettelo) held by EVIRA Finnish Food Safety Authority Evira.

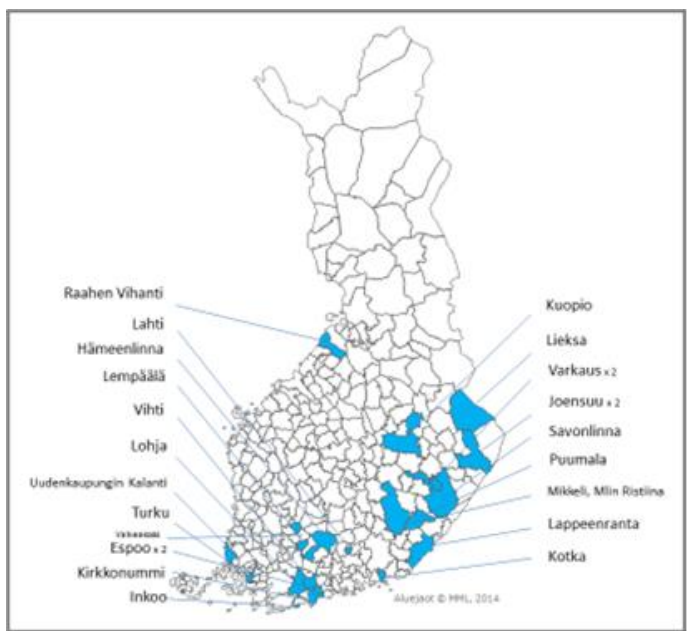

Fig. 1: Sites of wild Finnish truffles located in Finland

\section{BACKGROUND OF RESEARCH ON WHITE TRUFFLES IN FINLAND}

The research on the wild truffles occurring in the Fenno-Scandinavian region is scarce [10] and is still flourishing. Until the last decade, the most records of truffle species in this region was held by Denmark (6 white and 3 black truffle species), and Sweden (5 tuber species including 2 black truffles) [9]. However, in Finland, truffles were not a part of the culinary tradition, and the first records of truffles were T. maculatum, T. scruposum, and T. borchii $[8,9]$ followed by reports on $T$. anniae and $T$. foetidum. $T$. anniae is a white truffle variety that was found in eastern Finland. Wang et al. (2013) [8] studied morphological and molecular characterization of ectomycorrhizae of $T$. anniae obtained from pine, breach, oak, aspen, and orchid trees and reported geographical disjuncts in colonization of $T$. anniae which suggests possibilities of its adaptation in the new habitats. There are no other reports available on this truffle variety in the scientific literature to the best of our knowledge. This calls for further investigation to study biochemical characteristics of this truffle and to explore the possibilities for plantation of this wild variety to generate new business revenue.

Shamekh et al. [10] investigated soil habitat characteristics and forest vegetation of the natural habitats of white truffles in Finland and observed colonization of T. maculatum and $T$. scruposum majorly with $P$. abies. T. borchii was the first Finnish truffle variety with gastronomic value [9] which obtained place in Italian truffle market. However, many other Finnish wild truffles are yet to be explored for their commercial potential. There is a huge scope to study other Finnish wild white truffle varieties, and to explore their commercial value in the international market.

Wang et al. [8] discovered a substantial spontaneous fruiting of white truffles in Puumala, Finland. Phylogenetic analyses (using molecular methods) showed that these truffles belong to the $T$. anniae species complex. Earlier this species was considered to be uncommon, and restricted only to the Pacific Northwest, USA.Furthermore, there is a confusion of the identities due to the differing species 
concepts. For instance, Mello et al. (2000) [17] has reported the close morphological resemblance of $T$. borchii to $T$. maculatum. In addition to the truffle species discovered and identified so far in Finland, several environmental samples remain undistinguished since they have been detected only as ectomycorrhizae, while ascomata of these species are yet to be discovered and described [8]. Researchers have hypothesized the significance of other fungal and even bacterial communities associated with truffles in their occurrence/growth [18]. Therefore, apart from a comprehensive understanding of the soil conditions, host plant, and morphological properties of truffles, a thorough knowledge on the use of molecular tools for the identification and distinguishing of true truffles and the associated microbial community also becomes necessary.

The true wild white Finnish truffles found in Finland are shown in Figure 2. Various truffle-like fungi received from Finnish people were studied at JTC in order to confirm the identity and some of the false truffles of genus Hydnotrya, Rhizopogon, Scleroderma, and Elaphomyces were differentiated (Figure 3) [19]. Attempts have been made earlier to resolve these truffle-like fungi on genetic basis from true truffles [20].

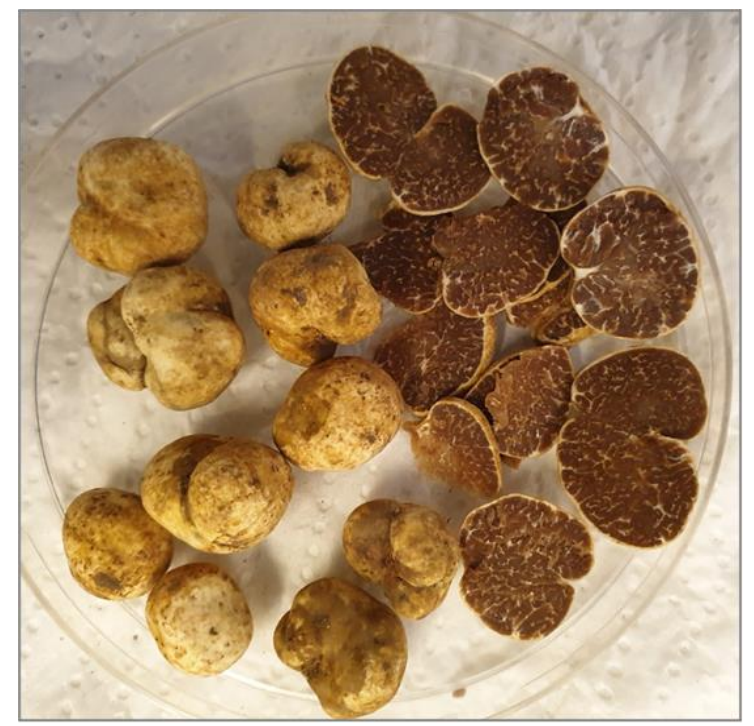

Fig. 2: Finnish wild white truffles received at JTC

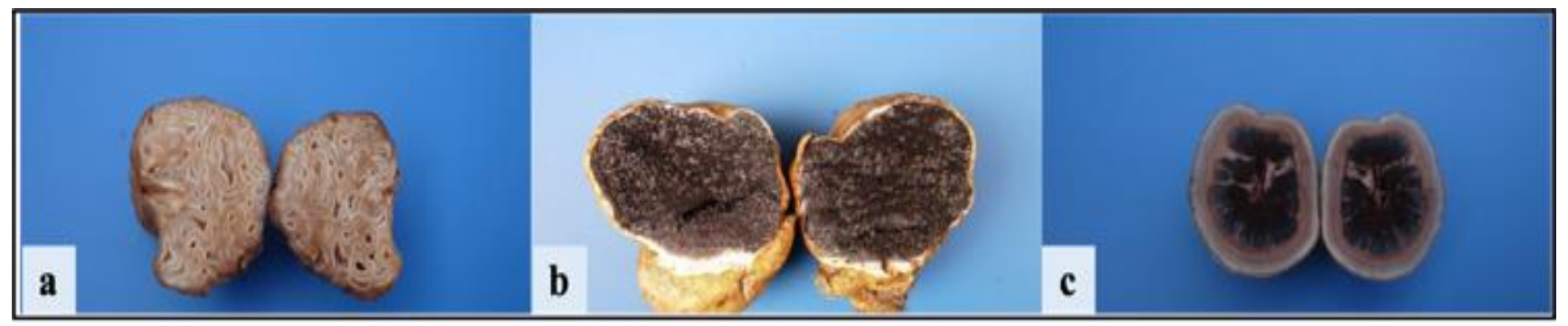

Fig. 3: Truffle-like fungi (false truffles) received by JTC from Finnish people, differentiated from real truffles as fungi of the genus a) Hydnotrya, b) Scleroderma and c) Elaphomyces.

\section{A COMPARISON OF SOIL PROPERTIES AND GROWTH OF WHITE TRUFFLES}

\section{A. Chemical properties of soil}

The $\mathrm{pH}$ and composition of soil plays a crucial role in the survivability and growth of truffles. As a rule of thumb, soils with a $\mathrm{pH}$ in slightly basic range make the truffle beds most productive. The $\mathrm{pH}$ of most truffles beds varies between $7.0-8.9$ (averaging to $7.9 \pm 0.4$ ) and the $\mathrm{pH}$ of $95 \%$ of soils showing truffle growth ranges between 7.5 and 8.3 [21]. In their ectomycorrhizal form, the substantial environmental challenge that white truffles face, is the high soil $\mathrm{pH}$ values (7-8.5) which is typically observed in their natural habitats [22].

In a study on finding and identification of wild truffles in Finland, Salem et al. (2009) [10] reported the $\mathrm{pH}$ of 6.6 of the forest soil where the truffles were found, which is higher than the $\mathrm{pH}$ of typical Finnish forests, which ranges between 4.3-4.5. The truffles found in this study were later identified as $T$. maculatum and T. scruposum[10]. In another studies [8,9], where the earliest (supposedly the first) findings of $T$. anniae and T. foetidum were reported in Finland, the soil $\mathrm{pH}$ was found out to be 6.5. The authors stated the reasoning for higher $\mathrm{pH}$ as a former use of the site as a farm field and/or the use of lime fertilizers. T. foetidum has been reported to grow well in near neutral soil and has shown a unimodal relationship with the soil $\mathrm{pH}$, with a $\mathrm{pH}$ optima between 5.5-5.9 [15]. Researchers have also reported the findings of $T$. maculatum along with T. magnatum, in soil with a $\mathrm{pH}$ of 8.0 \pm 0.2 in Italy $[23,24]$. Moreover, a study on the suitability of fluvial planes for T. magnatum production has also reported an alkaline $\mathrm{pH}$ of the soil environment [25]. These reports point towards the need of an alkaline soil environment for the white truffle T. magnatum. In a study performed by Timonen and Kauppinen [26] in forest habitats of Southern Finland, the probable findings of ectomycorrhizas of $T$. maculatum Vittad. identified by sequencing techniques, in soil with $\mathrm{pH}$ of 4.5-4.6 was reported. These results are in contradiction with the results of aforementioned study by Bertini et al. (2006) which indicated the presence of T. maculatum in a soil with an alkaline $\mathrm{pH}$. Amongst the clade of white truffles (of the genus Tuber) that show unimodal relationship with $\mathrm{pH}, T$. borchii has been reported to show the lowest $\mathrm{pH}$ optima, which lies between 4.5-4.99 [15]. Again, this is in contradiction to a study where $T$. borchii was reported to grow naturally in a soil of $\mathrm{pH} 7.5$ [27]. In conclusion to these studies, the major difference between the white truffles found in Finland and other parts of Europe is the growth of truffles in lower $\mathrm{pH}$ soils in case of the former. The occurrence and growth of white Truffles would depend not only on $\mathrm{pH}$, but also on other chemical as well as physical properties of soil, which are influenced greatly by their geographical location. 
Hence, appropriate techniques need to be developed and used to maintain the soil $\mathrm{pH}$ in the optimal range and monitor physico-chemical properties of soil for truffle growth.

Another important consideration that influences Truffle growth/cultivation is the physiochemical composition of the soil. Although very few studies have reported on the chemical composition of soil, specifically where white truffles or their ectomycorrhiza have been found, they still add value to understanding the needs of white truffles such as T. anniae, T. maculatum, T. magnatum, and T. borchii. Some of the results of these studies that have reported the chemical composition of the soil for elements such as Calcium $(\mathrm{Ca})$, Magnesium (Mg), Potassium (K), Phosphorous (P), and total organic carbon have been compared in Table 1.

Table 1: Chemical composition of soil for various truffles under study

\begin{tabular}{|c|c|c|c|c|c|c|c|}
\hline $\begin{array}{l}\text { Truffle species } \\
\text { studied }\end{array}$ & Location & $\begin{array}{l}\text { Calcium } \\
\text { (Ca) }\end{array}$ & $\begin{array}{l}\text { Magnesiu } \\
\text { m (Mg) }\end{array}$ & $\begin{array}{l}\text { Potassium } \\
\text { (K) }\end{array}$ & $\begin{array}{l}\text { Phosphoro } \\
\text { us (P) }\end{array}$ & $\begin{array}{l}\text { Total } \\
\text { organic } \\
\text { carbon }\end{array}$ & Reference \\
\hline T. anniae & $\begin{array}{l}\text { Puumala, } \\
\text { Finland }\end{array}$ & $3500 \mathrm{mg} / \mathrm{L}$ & $470 \mathrm{mg} / \mathrm{L}$ & 360 & 190 & $11.5 \%$ & [8] \\
\hline $\begin{array}{l}\text { T. maculatum/ } \\
\text { T.rapaeodorum/ } \\
\text { T. borchii }\end{array}$ & $\begin{array}{l}\text { PornainenH } \\
\text { irvisuo, } \\
\text { Finland }\end{array}$ & 498 ppm & $44.4 \mathrm{ppm}$ & $76.3 \mathrm{ppm}$ & $4.48 \mathrm{ppm}$ & $10.0 \%$ & [26] \\
\hline T. borchii & $\begin{array}{l}\text { Marina di } \\
\text { Ravenna, } \\
\text { Ravenna, } \\
\text { Italy }\end{array}$ & $8.4 \%$ & - & - & $\begin{array}{l}24 \mu \mathrm{g} / \mathrm{mL} \\
\text { (extractable } \\
\text { ) }\end{array}$ & $1.3 \%$ & [27] \\
\hline T. magnatum & $\begin{array}{l}\text { Central } \\
\text { Italy }\end{array}$ & $\begin{array}{l}16.24 \\
\text { cmole/kg }\end{array}$ & $\begin{array}{l}3.14 \\
\text { cmole/kg }\end{array}$ & $\begin{array}{l}0.42 \\
\text { cmole/kg }\end{array}$ & - & $1.96 \%$ & [28] \\
\hline T. magnatum & $\begin{array}{l}\text { Pesaro-Urbi } \\
\text { no, Italy }\end{array}$ & - & $\begin{array}{l}392.7 \\
\mathrm{mg} / \mathrm{kg}\end{array}$ & $\begin{array}{l}271.6 \\
\mathrm{mg} / \mathrm{kg}\end{array}$ & $4 \mathrm{mg} / \mathrm{kg}$ & $27.4 \mathrm{~g} / \mathrm{kg}$ & [23] \\
\hline
\end{tabular}

-: not mentioned

The results from these studies have made the comparison of truffle-producing soil and reference soil (where no truffles have been found) easier, and has ultimately helped in understanding the role of the chemical composition of the soil in truffle occurrence/growth. For instance, Wang et al. (2013) who studied the occurrence of T. anniae in Puumala, Finland, reported a concentration of $\mathrm{Ca}$ and $\mathrm{Mg}$ that was 12 and 18 times higher, respectively, in truffle-producing soil than in the reference soil. The authors also reported a 6 times higher concentration of Potassium, and around 50 time higher concentration of Phosphorous in the truffle-producing soil.

The total organic carbon was also high $(11.5 \%)$ in truffle-producing soil than in the reference soil $(2.9 \%)$. The differences in the chemical composition of soil can be seen not only with variations in the fields/areas, but also with variations in the depth of the soil. For instance, while studying the mycorrhizal colonization patterns, Timonen and Kauppinen [26] reported the differences in the soil collected from the same forest location from Southern Finland, but at varying depths. The authors could notice substantial differences in soil composition where the content of $\mathrm{Ca}, \mathrm{Mg}$, $\mathrm{P}, \mathrm{K}$, and $\mathrm{Fe}$ at a depth of 20-25 $\mathrm{cm}$ was 2-3 times less than at a $5-10 \mathrm{~cm}$ depth. Thus, almost all of the elements tend to decrease in proportion, with increasing depths of soil. Similar methodology was used by Wang et al. [8] to gain insights in the soil composition where $T$. anniae truffles were found, where the authors collected the soil at varying depths ( 5 and $10 \mathrm{~cm}$ ) but mixed it for analysis to understand the average/mean range of the elements. 


\section{B. Physical characteristics of soil}

The physical characteristics of soil have been another major studied factor in research focusing on truffle cultivation. The nature of soil is studied based on its composition of coarse sand $(0.2-2.0 \mathrm{~mm})$, fine sand $(0.02-0.2$ $\mathrm{mm})$, silt $(0.002-0.02 \mathrm{~mm})$, and clay $(<0.002 \mathrm{~mm})$ [8]. Wang et al. [8] reported the findings of $T$. anniae in Pumala, Finland, where the soil showed an abundance of coarse sand (75\%). The other soil components were $12 \%$ fine sand, $9 \%$ silt, and $4 \%$ clay. The authors also studied a reference soil from an adjacent non-truffle producing field, where the composition was $45 \%, 38 \%, 11 \%$, and $6 \%$, of coarse sand, fine sand, silt, and clay, respectively. In another study by Bragato et al. [25], the authors studied the soil composition in terms of sand, silt, and clay, for T. magnatum producing area (ČepićPolje, Croatia).

The authors reported a higher proportion of silt in productive soil $(65.1 \%)$ as well as reference soil $(53.3 \%)$, in comparison to sand and clay. The proportion of sand was $12.5 \%$ and $7.7 \%$, and that of clay was $22.4 \%$ and $37.2 \%$, for productive and reference soils, respectively. In contradiction to this, a higher proportion of sand $(55.4 \%)$ has been reported for T. magnatum soil from Central Italy, as opposed to $24.1 \%$ and $20.5 \%$ of silt and clay, respectively [28]. This is in agreement with a report for soil from a T. magnatum truffière, from Central Italy, where the average composition of sand, mud, and clay was reported 354.0, 470.7, and $175.3 \mathrm{~g} / \mathrm{kg}$ soil, respectively [23]. The dynamics of sedimentation also play a crucial role in the occurrence and growth of truffles such as $T$. magnatum. T. magnatum has been reported to grow in the present-day flood deposits that run next to the streams where moist soil with a loose and weakly organized granular/subangular structures are observed [28]. The soil belonging to Calcaric Fuvisol type (young alluvial soil) that is rich in lime is suitable for the growth of T. magnatum [28].

\section{TRUFFLES AND THEIR HOST PLANTS}

The formation of ectomycorrhizal association of truffles with the roots of the host plant is a well-known fact. The life cycle of truffles can be divided into three phases: the vegetative growth of mycelium; contact with the roots of the host plant and formation of the ectomycorrhiza; and finally the development of the hypogeous fruit body [29]. Thus, apart from knowing the soil parameters it is also crucial to understand the cultivar of host plant to achieve successful truffle cultivation.

Truffles have been known to grow in association with various tree cultivar. Yet, Oak (Quercus robur) is a well-known of the host plants for growing black and burgundy truffles. Howbeit, the Finnish truffles reported so far have been found in association with other trees such as birch, pine and spruce [9]. For instance, Shamekh et al. [10] reported the findings of $T$. maculatum and T. scruposum in
Finland, where the truffle site was predominantly covered with a vegetation of spruce trees (Piceaabies) with a few pine trees. Another important occurrence of truffles in Finland was reported by Wang et al. [8] for the species $T$. anniae, where the site is dominated by Pinus sylvestris trees (nearly 20-30 years old) with some Betula pendula Roth scattered amongst them. These authors also included $T$. anniae samples found at a site in Alaska, that were found growing under Alnus sp. trees intermixed with trees of Picea and Betula species. Furthemore, another study by Orczán et al. [9] lead to the findings of T. foetidum for the first time in Finland. These authors reported the findings of T. foetidum in a forest near Lahti, Finland, where the vegetation was dominated by Norway spruce $(P$. abies) with scattered birch (Betula sp.) and pine (P. sylvestris).

Outside Finland, the ectomycorrhizal association of $T$. borchii mycelia with Pinus pinea roots has also been reported to occur naturally at a site in Ravenna, Italy [27]. These findings point at the possibility that the trees such as $P$. abies, $B$. pendula, $P$. sylvestris, and $P$. pinea might be potential hosts for truffles such as $T$. maculatum, $T$. anniae, $T$. foetidum, and T. borchii. Another study on the occurrence of truffle ectomycorrhiza of Tuber species (T. maculatum/T. rapaeodorum/T. borchii identified by phylogenetic analysis) was reported for their association with Tiliacordata trees in southern Finland [26]. T. maculatum has also been reported for its association with Populus deltoides trees in ČepićPolje, Croatia [25]. T. magnatum has been reported to grow in Croatia in areas where common oak, oriental hornbeam (Carpinusorientalis Mill.), elm (Ulmus minor Mill.), common maple (Acer campestris L.), poplars (Populus spp.) and willows (Salix spp.) grow [30]. Considering the significant role that the host trees play in the occurrence/growth of various truffle species, their knowledge is of utmost importance in the cultivation of truffles.

\section{MORPHOLOGICAL INVESTIGATION}

Ascomata of various truffles species have been known worldwide for their gastronomic value. However, the ascocarp also serves as an important tool in the morphological identification of truffles species. The identification of truffles can be carried out at a primary level based on their macro and micro morphology. The characteristics taken into consideration include the ascomata (diameter, color, and patterns), gleba (color, pattern, and aroma), peridium (thickness, layers, and color), and asci (shape, color, patterns, and number). In some cases, where the fruiting body (ascocarp) is yet to develop, the ectomycorhizza can be studied for their microscopic characteristics, based on which a primary identification may be carried out. Truffles can be distinguished easily based on the morphology of ascocarp and ectomycorrhiza [29]. The macro/micro morphological features of various white truffle species are given in Table 2 . 
Table 2: Differentiating characteristics of various parts of white truffle species

\begin{tabular}{|c|c|c|}
\hline $\begin{array}{l}\text { Truffle } \\
\text { species }\end{array}$ & Differentiating characteristics & References \\
\hline T. anniae & $\begin{array}{l}\text { Ascomata: } 5-25 \mathrm{~mm} \text { in diameter, subglobose/irregularly subglobosestereothecia; surface } \\
\text { pale greyish; orange when young, darker with more brownish tinge when mature } \\
\text { Peridium: } 120-200 \mathrm{~mm} \text { thick, double layered; pseudoparenchymatous with globose to } \\
\text { subglobose cells } \\
\text { Gleba: white when young, brownish when mature, marbled with well-developed paler } \\
\text { veins } \\
\text { Odor: faint but pleasant aroma }\end{array}$ & {$[8]$} \\
\hline T. foetidum & $\begin{array}{l}\text { Ascomata: } 9 \mathrm{~mm} \text { in diameter; pale ochraceous, brownish surface } \\
\text { Peridium: } 330-380 \mu \mathrm{m} \text { in thickness; pseudoparenchymatous with polygonal/roundish } \\
\text { cells } \\
\text { Gleba: was paler than the surface, and rarely marbled } \\
\text { Odor: unpleasant }\end{array}$ & [9] \\
\hline T. magnatum & $\begin{array}{l}\text { Ascomata: hypogeous, irregular, lobed, gibbous, sometimes flattened; pale ochre or } \\
\text { greenish } \\
\text { Peridium: pseudoparenchymatous, with subglobose to ovoid cells } \\
\text { Gleba: soapy texture, pale yellow, reddish brown, with flesh-red spots, marbled with } \\
\text { numerous, thin, whitish veins } \\
\text { Odor: strong, with mixture of methane gas, fermented cheese and garlic }\end{array}$ & {$[31]$} \\
\hline T. borchii & $\begin{array}{l}\text { Peridium: } 500-600 \mu \mathrm{m} \text { in thickness, outer half pseudoparenchyma with isodiametric cells } \\
\text { Gleba: merged with the inner layer of peridium, beige, reddish brown, marbled, with } \\
\text { white, wide, veins arising from periphery } \\
\text { Odour: garlicky, pleasant when young, strong and unpleasant when mature }\end{array}$ & {$[17,32]$} \\
\hline
\end{tabular}

As a rule of thumb, white truffles might show common morphological characteristics such as abundant ectomycorrhizal system, densely ramifying, monopodial to pyramidal. The main axes could be around 3-4 mm in length, either straight or slightly bent [33]. The ends are generally unramified, $0.7 \mathrm{~mm}$ in length and $0.2-0.3 \mathrm{~mm}$ in diameter, cylindrical or slightly tapering, with tips lighter than other parts. The surface is densely spiny with cystidia, without rhizomorphs. Cystidia could be frequent, apical to lateral, and colorless or yellow [33].

Although morphological studies serve as an important tool for identification of truffle species, distinguishing various species within the genera Tuber (such as T. magnatum, T. borchii, T. maculatum, etc.) can be difficult [29] due to morphological similarities. These morphological similarities make the differentiation of the white truffles with high economic value from the ones with no or low economic significance difficult even for the truffle experts. Truffles such as $T$. borchii have excellent market value. Other truffles with similar morphology may be sold falsely or unknowingly as $T$. borchii. In such cases, it is crucial to ensure the exact species of the truffle to ensure its market safety, purity, and high economic value. This can be carried out using molecular tools such as DNA analysis, which have been discussed in the subsequent section.

\section{MOLECULAR INVESTIGATION}

The principle generally used for molecular analysis involves extracting DNA from samples, amplifying it using PCR technique, and characterization by RFLP analysis and/or sequencing and comparing with various DNA sequence databases. The DNA may be extracted from various sources such as ascomata [8], [9], [23], [27] ectomycorrhiza [8], [23], [26], [27], or from soil sample as seen in certain studies [18].

The DNA sequence that is primarily focused upon is the internal transcribed spacer (ITS) which is roughly 600 base pairs long and lies in the ribosomal tandem repeat gene cluster of the nuclear genome [34]. The ITS sequence is 
further divided into 2 regions; ITS1 and ITS2 which are separated by 5.8S rRNA gene [34]. In vast majority of fungi, the genes for $18 \mathrm{~S}, 5.8 \mathrm{~S}$, and $28 \mathrm{~S}$ rRNA are highly conserved, thus allowing the design and use of "universal primers" such as ITS primers for fungal DNA bar coding [34]. Several researchers have studied the various white truffle species using molecular tools with ascocarp or ectomycorrhizal samples as the DNA source. For instance species such as $T$. anniae [8], T. foetidum [9], T. borchii, and T. maculatum [17] have been studied using sequence analysis of DNA isolated from ascocarps. RFLP has also been used to study species such as $T$. anniae [8] and $T$. borchii [27] using ectomycorrhizal samples.

A hypothesis suggesting the impact of soil-borne communities on truffle production has been put forth [18]. Apart from their use for the identification/classification of the truffle species, molecular methods have also been used to study the microbial communities associated with the wild white truffles such as T. magnatum [18] and T. borchii [27]. Thus, with the promising molecular techniques, the possibility of studying the white truffle-associated microbial communities, the effect of the truffles on the biodiversity, and its utilization for optimal white truffle cultivation in Finland could be explored. Furthermore, confirmation of the exact species of the fine white truffles such as $T$. borchii which have high market price could be done using molecular tools. This could ensure higher economic value of the truffles in Finish markets, considering that these fine truffles do not have a traditional market place in Finland. This could lead to substantial economic growth of rural Finnish areas.

\section{OPPORTUNITIES FOR CULTIVATION OF NEW TRUFFLE VARIETIES IN FINLAND}

Shamekh et al. [1] successfully cultivated $T$. aestivum inoculated Southern European provenance Quercus robur seedlings in the boreal region of Finland. In this study, various plant management practices and optimized soil conditions, and irrigation methods suitable for the growth of oak seedlings were studied. The morphological and molecular analysis of root samples collected from these oak seedlings confirmed the growth of $T$. aestivum. This study confirmed that successful plantation of new varieties of truffles is possible with proper plant management and cultivation practices in extreme winter conditions of Finland.

Various truffles have different fruiting/ harvesting season. Harvesting of $T$. aestivum is carried out during June to August; T. melanosporum is harvested during December to March, whereas $T$. uncinatum is harvested between September and December [35]. In Finland, the truffle harvest season falls during late July and continues until November, which is the off season for white truffles in rest of the Europe. Thus, the productive season of Finland can be used to grow white truffles such as $T$. borchii which have high economic value, while the rest of the European region has an off season for white truffle growth. Growing these white truffles in their off-season would result in steady supply as well as a high market value. Amongst the truffles discovered in Finland so far, owing to its culinary value, the finest one seems to be $T$. borchii, which is still under confirmatory studies using molecular tools. Considering the significant value of such truffles, establishing their cultivation orchards in Finland could be of great economic importance. With the knowledge of the appropriate soil conditions and host plants species, establishing truffle farms for the fine truffles such as $T$. borchii is possible. With this comprehensive knowledge, various truffles can be grown off-season by establishing truffle orchards in rural Finnish areas, thus generating potential business opportunities throughout the year. This could also help in ensuring a market position for truffles which do not have a traditional market place in Finland. Ultimately, this would invite employment opportunities and thus help boost the rural economy.

\section{CONCLUSION}

Considering the sparse reports, it seems that Finland has not been a traditional truffle-producing location, nor were truffles a part of Finnish diet. Despite several truffle species such as T. maculatum, T. scruposum, and T. foetidum being discovered recently, it appears that truffles have had a long history of presence in Finland. Truffle species found in Finland which have significant economic value such as $T$. borchii, are still under confirmatory investigations. A comprehensive knowledge of the soil properties, host plants, favourable environmental conditions, as well as the methods for identification of truffles seems to be decisive in successful truffle cultivation. With this knowledge and appropriate orchard-management techniques, it would be possible to grow truffles with high economic value such as $T$. borchii as well as non-native black truffle species. This would in turn bring various employment opportunities to the rural areas of Finland and ultimately contribute to considerable economic growth.

\section{DECLARATION OF COMPETING INTEREST}

The authors declare that they have no known competing financial interests or personal relationships that could have appeared to influence the work reported in this paper.

\section{ACKNOWLEDGMENT}

The authors wish to thank Mr. Antti Kinnunen for administrative service and Madame Aija Myriin for technical assistance. We appreciate and are grateful for the financial support of Regional Council of Southern Savo, Finland.

\section{REFERENCES}

[1] Shamekh S, Grebenc T, Leisola M, Turunen O. The cultivation of oak seedlings inoculated with Tuber aestivum Vittad. in the boreal region of Finland. Mycol Prog 2014, 13, 373-380.

[2] Wang S, Marcone MF. The biochemistry and biological properties of the world's most expensive underground edible mushroom: Truffles. Food Res Int 2011, 44, 2567-2581.

[3] Shah N, Usvalampi A, Chaudhary S, Seppänen-Laakso T, Marathe S, Bankar S, Singhal R, Shamekh S. An investigation on changes in composition and antioxidant potential of mature and immature summer truffle (Tuber aestivum). Eur Food Res Technol 2020, 1-9.

[4] Hamza A, Zouari N, Zouari S, Jdir H, Zaidi S, Gtari M, Neffati M. Nutraceutical potential, antioxidant and antibacterial activities of Terfezia boudieri Chatin, a wild edible desert truffle from Tunisia arid zone. Arab J Chem 2016, 9, 383-389.

[5] Morte A, Zamora M, Gutiérrez A, Honrubia M. Desert truffle cultivation in semiarid mediterranean areas. In: Azcón-Aguilar C, Barea JM, Gianinazzi S, Gianinazzi-Pearson V, (Eds.) Mycorrhizas Functional Processes and Ecological Impact. Springer, Berlin, Heidelberg. pp. 221-233.

[6] Reyna-Domenech S, García-Barreda S. European Black Truffle: Its Potential Role in Agroforestry Development in the Marginal Lands of 
Mediterranean Calcareous Mountains. In Rigueiro-Rodróguez A, McAdam J, Mosquera-Losada MR, (Eds.) Agroforestry in Europe. Springer, Dordrecht. pp. 295-317

[7] Wedén C, Pettersson L, Danell E. Truffle cultivation in Sweden Results from Quercus robur and Corylus avellana field trials on the island of Gotland. Scand J For Res 2009, 24, 37-53.

[8] Wang X H, Benucci G M N, Xie X D, Bonito G, Leisola M, Liu P G, Shamekh S. Morphological, mycorrhizal and molecular characterization of Finnish truffles belonging to the Tuber anniae species-complex. Fungal Ecol 2013, 6, 269-280.

[9] Orczán KÁ, Turunen O, Merényi Z, Rudnóy S, Bratek Z, Shamekh S. Tuber foetidum found in Finland. Mycotaxon 2010, 114, 127-133.

[10] Shamekh S, Donnini D, Zambonelli A, Leisola M. Wild Finnish Truffles. Acta Bot Yunnanica 2009, 69-71.

[11] Hilszczanska D, Sierota Z. First attempt towards cultivation of Tuber aestivum in Poland. Acta Mycol 2010, 47, 209-212.

[12] Benucci G M N., Bonito G, Falini L B, Bencivenga M. Mycorrhization of Pecan trees (Carya illinoinensis) with commercial truffle species: Tuber aestivum Vittad. and Tuber borchii Vittad. Mycorrhiza. 2012 , 22, 383-92.

[13] Linde C C, Selmes, H. Genetic diversity and mating type distribution of Tuber melanosporum and their significance to truffle cultivation in artificially planted truffiéres in Australia. Appl. Environ. Microbiol. 2012, 78, 6534-6539.

[14] Lefevre, C.K., Hall, I.R.. The status of truffle cultivation: A global perspective. Acta Hortic. 2001, 556, 513-520.

[15] Gryndler M, Šmilauer P, Št’ovíček V, Nováková K, Hršelová H, Jansa, J. Truffle biogeography-A case study revealing ecological niche separation of different Tuber species. Ecol. Evol. 2017, 7, 4275-4288.

[16] Citterio B, Cardoni P, Potenza L, Amicucci A, Stocchi V, Gola G, Nuti M. Isolation of Bacteria from Sporocarps of Tuber Magnatum Pico, Tuber Borchii Vitt. and Tuber Maculatum Vitt. In In Bonfante, P. Nuti, M., Stocchi, V. (Eds.) Biotechnology of Ectomycorrhizae. Springer, Boston, MA; pp. 241-248

[17] Mello A, Vizzini A, Longato S, Rollo F, Bonfante P, Trappe JM. Tuber borchii versus Tuber maculatum: Neotype studies and DNA analyses. Mycologia 2000, 92, 326-331.

[18] Mello A, Miozzi L, Vizzini A, Napoli C, Kowalchuk G, Bonfante P. Bacterial and fungal communities associated with Tuber magnatum-productive niches. Plant Biosyst 2010, 144, 323-332.

[19] Juva Truffle Center. http://juvatruf.asiakkaat.sigmatic.fi/en/wild-truffles/ (Accessed 27 July 2020)

[20] Landvik S, Egger KN, Schumacher T. Towards a subordinal classification of the Pezizales (Ascomycota): Phylogenetic analyses of SSU rDNA sequences. Nord J Bot 1997, 17, 403-418.

[21] Jaillard B, Oliach D, Sourzat P, Colinas C: Soil Characteristics of Tuber melanosporum Habitat. In True Truffle (Tuber spp.) in the World. Zambonelli A, Iotti M, Murat C (Eds). Springer International Publishing Switzerland; 2016, 169-190.

[22] Pavić A, Stanković S, Saljnikov E, Krüger D, Buscot F, Tarkka M, Marjanović Ž: Actinobacteria may influence white truffle (Tuber magnatum Pico) nutrition, ascocarp degradation and interactions with other soil fungi. Fungal Ecol 2013, 6, 527-538.

[23] Bertini L, Rossi I, Zambonelli A, Amicucci A, Sacchi A, Cecchini M, Gregori G, Stocchi V. Molecular identification of Tuber magnatum ectomycorrhizae in the field. Microbiol Res 2006, 161, 397-401.

[24] Dincă M, Dincă LC. Truffles and soil. Res J Agric Sci 2015, 47, 44-50

[25] Bragato G, Vignozzi N, Pellegrini S, Sladonja B. Physical characteristics of the soil environment suitable for Tuber magnatum production in fluvial landscapes. Plant Soil 2010, 329, 51-63.

[26] Timonen S, Kauppinen P: Mycorrhizal colonisation patterns of Tilia trees in street, nursery and forest habitats in southern Finland. Urban For Urban Green 2008, 7, 265-276.

[27] Zambonelli A, Iotti M, Rossi I, Hall I. Interactions between Tuber borchii and other ectomycorrhizal fungi in a field plantation. Mycol Res 2000, 104, 698-702.

[28] Bragato G, Marjanović ŽS. Soil Characteristics for Tuber magnatum. In True Truffle (Tuber spp.) in the World. Zambonelli A, Iotti M, Murat C (Eds). Springer International Publishing Switzerland; 2016, 191209.

[29] Bertini L, Potenza L, Zambonelli A, Amicucci A, Stocchi V. Restriction fragment length polymorphism species-specific patterns in the identification of white truffles. FEMS Microbiol Lett 1998, 164, 397-401.

[30] Bragato G, Sladonja B, Peršurić D. The soil environment for Tuber magnatum growth in Motovun Forest, Istria. Nat Croat 2004, 13, 171-185.
[31] Rodríguez A, Tuber magnatum Pico. 2008 , https://www.trufamania.com/Tuber magnatum English.htm. (Accessed 7 Aug 2020)

[32] Rodríguez A, Tuber borchii Vittadini. 2008 , https://www.trufamania.com/Tuber borchii English.htm. (Accessed 7 Aug 2020)

[33] Kovács GM, Jakucs E. Morphological and molecular comparison of white truffle ectomycorrhizae. Mycorrhiza 2006, 16, 567-564.

[34] Xu J. Fungal DNA barcoding. Genome 2016, 59, 913-932.

[35] Agri-Truffle, Saint-Maixant, France. https://www.agritruffe.eu/en/truffle-trees-trufficulture-english/harvest ing-truffle/. (Accessed 27 July 2020)

Seema R. Bajaj Dr. Bajaj is a PhD in Food Engineering and Technology from Institute of Chemical Technology, Mumbai, India. She has 8 years of research experience from industry and academia.

Salem Shamekh Dr. Shamekh obtained his D.Sc. degree from Helsinki University of Technology, in 2002. He worked as a Researcher at VTT, Finland from 1991-2003, and as a Senior Scientist at Aalto University, Finland from 2003-2016. He has been working as the Director of Juva Truffle Center, Juva, Finland from 2007 till present. He is a well-known scientist in truffle cultivation and research worldwide. 